Milica D. JOTOV*

University of Belgrade, Faculty of Philology, Japanese language and literature

\title{
MULTINATIONAL CORPORATE RELATIONS IN JAPANESE COMPANY TOYOTA WITH OVERLOOK ON COOPERATION WITH PHILIPPINES
}

\begin{abstract}
This paper aim is to consider the issue of the special management and production model developed at Toyota, and its contribution to the development of other economies in the world, with special reference to production in the Philippines.

Japan was the first country in Asia to embark on a path of modernization and as such, became a model for the surrounding countries. The Philippines is one of the countries in the Asia-Pacific region that followed the path of change and adopted the Kaizen philosophy.

Japan has influenced more widely, globally, all companies in the world that strive to conduct this way of doing business in their own environment.

Toyota's business philosophy and the application of kaizen as a new model of corporate governance has become synonymous with quality corporate governance around the world and has influenced the establishment of new laws in the field of economy, culture and society, in a global context.
\end{abstract}

Key words: Japan, Philippines, Toyota, culture, economy.

\section{INTRODUCTION}

Researching Japanese language and literature with economical and historical backgrounds of the countries evolution the author of this paper got more interest in searching differences between his own people and their mentality and Japanese people and their mentality. Thanks to the language, he learned many things that cannot be found in books. Literature as one of the states of mind and indicator of present events in long history introduced him with many ideas that have emerged. Those ideas have helped him in understanding the basics of origin of one country he got interested in. As his interest has been rising, he found rather delightful sources of sparkling paths for even better understanding of one nation.

* Docent, jotovmimi@gmail.com 
Being happy to know that we live in fast world, were old values are being forgotten and new ones are being brought the author searched for examples were combining these two ways is possible. Globalization has brought us many either good or bad things to consider. Among many others, one bright thing is connection of the various people and their differences. Fast world with all longings for good old past time has maybe changed our perspective view on values, but has definitely not taken up our will to research.

Standing on people, many life philosophies and key points of existence have developed. We wanted to get a little bit deeper into the philosophy of people whose culture and historical existence followed with language studies we have to know better.

We have chosen one of the most significant companies to follow and using their way of expansion, growth and existence, try to explain the basics of one society. This company stands on loyalty and comprehension between people. They succeeded in developing in the new world, so we have chosen to follow their example in explaining the significance of multinational relations.

Because of carrying big interest in Asian cultures, languages and way of success, we wanted to show this multinational relations based on relations between one country and its best company and other Asian country where this company exists. They are the people from the same continent, but that does not refer to certainly same opinions and historical backgrounds. They live in constant symbiosis, constantly giving and taking one from another.

\section{SHORT HISTORY OF JAPANESE ECONOMY}

Nowadays Japan is one of the world's most powerful nation-state. Although, geographically it is not well positioned for building such a mighty status, in period of years, thanks to loyalty and hard work, Japanese people succeeded in raising and developing the country's state.

In the years that have passed, in many countries, economical growth was equal to industrialization. In one of the most significant period of Japanese history, Tokugawa period ${ }^{1}$, Japan was the country of neither high economy nor fast industrialization. A period, which occurred in Tokugawa rule known as Sakoku period $^{2}$ or seclusion policy, may be concerned as period of long-lasting peace and economic stagnation of the country. On the other side, it can be said that Japan's fast growth and rapid industrialization in the Meiji era ${ }^{3}$, occurred only

$1 \quad$ Rule under Tokugawa family, established in 1603 by Tokugawa Ieyasu and has lasted until 1868

2 Prevention from military alliances with European countries and outlawing of Christianity

3 Japan's modernization period, started in 1868 and lasted until 1912 
because of the political and economic institutions that have already been developed in Japan under the Tokugawa rule. In this period, almost all country's resources were coming from agriculture. Capitalistic institutions like wholesaling, infrastructure of roads and waterways, civil bureaucracy and tax system, already existed in the country when restoration began. Main thing that lacked in nineteenth century Japan was technology.

For Medieval Japan's economy and county institution, China was Greece and Rome. It is domain of Japan's ruling system, religion, and way of writing and of a lot more things that through centuries have developed and changed in world's unique example. Under this influence in Tokugawa Japan, few systems of ruling developed. The baku-han system where main sources as for the bakufu and daimyo, were rice taxes collected from the cultivators. Also, the caste system, where every person, except Shinto and Buddhist priests and doctors, belonged to a specific group. Moreover, honbyakusho system of collecting land taxes.

At the beginning of the nineteenth century Tokugawa rule begins to collapse and Russian, European and American trade with China leads to the incidental connections with Japan. These circumstances led to the ending of a seclusion policy. In search for monopoly and in questing resources from economically weak countries, European countries and America had spread their influence. At the dawn of one era, the other had begun. With U.S. Navy Commodore Matthew Perry demand on opening country for free trade with other countries, except with Holland and China, Japan entered a marvelous state of rapid growth. In order to avoid an experience of being colonized like their neighbors, Japan a country of a long-lasting peace decided to accept the industrialization needed for negotiating with European countries. In years to come Treaty of Amity and Commerce with the United States ${ }^{4}$ has been signed. Following this example, almost the same treaties were signed with Britain, Netherlands, France and Russia. Japan was faced with new problems waiting to be solved. It cannot be said that peace has been underestimated; just that change was needed in order to survive in a new world. Changes that have been made in a newly constructed Japanese society were recentralization and modernization of socio-economic, military and navy systems. This new world outside has brought many new ideas into the country. In order to reach already well-developed European countries Japan followed their example. Scholars from throughout the whole world were brought to Japan to teach, as well as young perspective students were sent abroad to learn. This was the beginning of mixed influences that have been unified into one pearl of will for expanding outrageous.

4 Treaty signed in 1858 between representatives of Perry and shogun 
With an introduction of a new military tactics, Japan wanted to expand its influence on neighboring countries. This is when a new thought of either good or bad Japanese militarism had ensured new relations and complex mixture of relations with nations and multinational cooperation, all in order to make a secure country for generations yet to come.

\section{RELATIONS BETWEEN JAPAN AND PHILIPPINES}

Relations between these two countries date back to the Muromachi period of Japanese history, where Japanese traders have been settled long before the Spanish colonization. Later after opening the doors, the cooperation has been continued. During the American period in Philippines' history, economical ties between these two countries have grown enormously. Later in World War II, Japan successfully overcame the United States rule in Philippines. These not very happy events have been made better in the postwar period when with friendly visits of highly ranked political leader cooperation between the two nations, have been concluded and forgotten diplomatic relations were reestablished. Thanks to the peaceful solution of a rising problem, Japanese companies and individual investors have begun to come back to Philippines and to build a fresh interest into cooperation between two countries, which has lead to the nowadays-unbreakable bound.

To build such an economical wonder, we can only presuming say, that closing and opening was indispensable. In these years a wonderful faith has emerged, values changed, and when they have come to an end of growing, they just opened for new knowledge. Knowledge that has been taken from all over the world granted prosperity. Prosperity that had been developed granted a success. Success that had been rapidly made has emerged a new light of learning and making.

This thought made a worldwide known way of success, Make more with less. Many of nowadays world's best companies established their philosophy on this motive. One among many others who was driven mad with this idea is exactly the establisher of today's best ranking company Toyota.

\section{TOYOTA THE WORLD'S BEST RANKING COMPANY}

Toyota Corporation was established in years of the biggest economical, political and social development. In an era of expansion of industry leaded by one motive European thought was transferred into a Japanese strength. Toyota quality, sustainability and reliability are just one of the main resources of its success. From the early years chiefs included not only their powers, but as well cooperation 
with co-workers. They listened others people opinions and like that they have built worlds one of the largest multinational companies. Positive mind and experience was and still is a way of sharing and growing strong. Even though this company is multinational and world spread, if take a better look, we will find it is a typical Japanese company. Considering this, there is one question that shows up. Is this the secret of becoming respected in the world? Combination of Japanese loyalty and abroad strength and ideas, may be the way of making the secure path through the rough world.

It can be said that for one multinational company it is very important to have a constant change and a great knowledge. This company has its offices in geographically different countries. Not only geography is the thing that changes the mind of the common good of the workers, but a constant flow of knowledge about cultural and historical differences and backgrounds as well. The mixture of international relations can be troublesome. Different nations with different environment and local markets wait to be adopted and researched. This is one of the reasons why constant flow of the knowledge is important. Knowledge of language, cultural and geographical environment, knowledge of people, because people are what one company stands on.

Toyota Corporation is one of maybe the best examples of international, multinational company. With their extraordinary research of what is necessity and what must be done, they kept going up. With going up, multinational company has never forgotten people, who brought the main idea of Make more with less and Adopt and adapt. For adopting company needs people, for adapting people needs company. Around the globe, many hidden objects carry key of understanding. Not trying to find them is a loss. Not trying to understand what is found is a mistake. For multinational relations this is the shell with many pearls inside, pearls that have been captured for many years. Cumulating this knowledge comes to finding a light of making success.

\section{TOYOTA WAY AND STRATEGY AND GLOBAL DEVELOPING}

Basically, Toyota was producing cars only in the domain country and exported them to the worlds market. Customers from abroad have progressively started to like good quality and good price. In order to maintain the customers interest in a new model, they begun producing cars only for the market abroad. Nevertheless, the increasingly big interest for Toyota products on the market outside Japan meant not only good prosperity for the sales section, but the loss of the great amount of money as well. Bigger export included bigger shipping costs. With the growth of demands from outside markets, need for a better solution was necessary. Solution to this was again accomplished thanks to people, 
who have been buying extremely good quality products. Japanese company realized that it was about time to build the factory there where the market is. High sales of specially made products for foreign market were recorded in USA and Europe, so the new model of business policy made it first steps. This is when Toyota, for the first time becomes company not only for the purposes of one nation, but also for purposes of nation on which their main market depended on. The products that are best sold are the ones you need for the prosperity. Company established its sectors and in order to keep good reputation and to keep market, they searched for the voice of the society they entered. Use of different nation they built an empire of cooperation. Following this examples they were attracted with the opportunities that have emerged in other countries. New expansion of opening factories has been made in Russia, China, Brazil, India and later on in the neighboring countries with developing economy such as Philippines, Taiwan, Malaysia, and others.

Toyota was not from the beginning reliable to the local minds, such as engineers and designers, they just continued with using Japanese minds for making products for exporting. At the beginning of world's fame, they trained exclusively Japanese engineers and designers. They offered them big amount of knowledge and specialization in their domain companies, and afterwards sent them to foreign countries, unprepared for cultural shock and possible misunderstandings between nations. This has been seen as a possible problem. Not only there were possible misunderstandings because of the different culture and the attitude towards the business, but these Japanese recruiters didn't have adequate knowledge of the market they reached in, while main production stayed in Japan. This way did not show like a good way of developing sale and making new ideas for new products. Soon Toyota realized that for expanding growth of products sale, engineers from the surrounding area are important. Even though Toyota Company in Japan mainly consists of insiders, Toyota Company in some foreign country can not relay on the same philosophy. Because Japanese people do not know what the trend among the residents of some other country is. They can only help building reputation and keep positive spirit among the new young workers. Listening to the local dealers and picking up the local talent was important. Identifying the local customers needs developed into the developing of market. Company in Japan already has developed to the particular stage and now what is necessary is new knowledge. They adapted Japanese way of management and the mentality of the people they are working with. Because in mentality of the people company is surrounded with, lays the essence of their existence. Moreover, in the existence lies the need. If there are not customers who will buy the products, unfortunately, company will suffer enormous losses. Therefore, company depends on customers. On the unknown field, the competition is extremely high, and in the fight for the market, not everyone is able 
to efficiently and effectively satisfy the unique needs of the customers. Innovation of the business must always be in progress, because needs change as the technology develops. The aim of Toyota Company was, to tend to the loyalty of workers and customers, so they constantly kept on searching around themselves in order to find a best solution for making innovative products. Materialization of ideas follows the innovation. The next aim of the company, if that can be said so, was the efficient and effective corporation between global needs and local opportunities.

Systematically company continued with searching and developing in still unknown areas. Worldwide resources are inexhaustible, so if searching is concentrated on the right side, new, better solutions can always be made. Toyota has from the beginning of the worldwide success; paid attention to the local needs in every region they had opened a company. Taking the best from the local knowledge, they accomplished using worldwide inexhaustible resources for effective production of high-quality products. With the opening companies in the world around they started, maybe for the first time, selling the products that have not been made in Japan. Speaking of innovation, a new motive, after the two extraordinary good business policies Make more with less and Adopt and adapt, has emerged. Combining worldwide thoughts, resources, people's ideas, needs of the locals, opportunities from the surrounding area they started a new business philosophy Learn local, act global. Together with the developing new markets, researching local needs and supplying necessary items they discovered that learning local is a new key that leads to success. For new still, undiscovered areas, there is a question of how to maintain their needs, so that is the acting global time for showing its lights. Producing cars out of Japan and selling them out of Japan was one of the reasons included in the act global part of the new company's business philosophy.

The good product sales depended upon the human resources in Asia and further efforts have been made in this area. Even though it is maybe easier to follow the path of the countries that are close to Japan, still each of them had their own trend. This trend has been researched in details and questioned wisely. With good results, new products, again, only for this specific market have been made.

Human resources were used not only as a customer but as designer and an engineer as well. They were used not as bait for buyers but also as a living source of eternal knowledge, which once again is important for a company that wants to become a multinational and for a company that stands on people working in it.

The above mentioned has shown a main change in the business philosophy and starts of a new era of multinational corporation. Toyota knowledge creation has changed from evolution of new studies in Japan and spreading it in the world, to evaluating new studies in the new reached area combining needs 
and trends of the local people. Thanks to this new strategy, they have proved the voice that has spread around about good quality and reliability.

The reasons for developing such a good motive may be found in the other competitive companies that have started spreading their influences. It is true that good sale of products has been noticed in Japan, but also, a great interest for upcoming European products has risen. Having accomplished success in Europe, European companies have started searching new resources. Asia has emerged as one interesting area. Looking forward to getting to know it better, they gradually started learning about the new opportunities. Following the examples of others Toyota has seen Europe and Asia as possible prosperity. Still unknown and untouched market has woken up a will for thinking and developing. Toyotas intention in reaching new markets, being effective, fast and innovative has been unfolded thanks to the other leading companies that have started questing new opportunities.

In most of the cases, having knowledge that is unused is like there is not knowledge at all. Therefore, everything new that has entered the company has carefully been observed, studied, questioned and considered as great possibility. To accomplish such an extraordinary task a lot of work has to be done. The work included not only the will for exploring the new world and worlds markets but people in the world as well. Trust among the researches in the existing company has gradually grown. Thanks to having gained the trust, search for new ways of better tomorrow brought light in development. Multinational company cultivated interest in Japanese people. Their loyalty and commitment to the job has a new sphere of interests. With those interests, all the difficulties that have occurred in contact with new personal achievements, common sense have risen on a very different level. Higher education followed the growth of personality. In addition, education and together with education acquired knowledge is the source. Unknown was seen as flow not as an obstacle. In the flow, many undiscovered currents appeared. "Going with the flow" made "building bridges" possible. Bridges that connect people, cultures and unclear differences, have been built. They have made uneasy became easy, impossible became possible and non-understandable became understandable. Easy understanding of impossible is just one-step of clear mind and will for develop and construction of multinational company with good reputation and healthy relation between co-workers.

\section{FOLLOWING THE NEW WORLD}

A very developed being, called human, through centuries has coexisted with Mother Nature. She has brought us to life, taught us how to survive in a fight with herself and how to reach far beyond the borders. We are just small figures 
in a big world. With the sources she gave us, we survived and we existed. Thanks to the blessed mixture of ingredients in each and every one of the living creatures, we found a colorful formula of life. However, in time, we have forgotten how to respect her. Human beings started losing their roots. For our everyday growing needs, we started drawing her life spirit. It was not that much bad at that moment, actually it was useful. Many good things got out from using Mother Nature's life spirit. We cannot compare the people sense of the environment in the past and now. Thanks to many years gathered and developed knowledge, sense has risen. We became conscious, that every new draw is a new tear of our beloved planet.

Electronic and technology era has many benefits and drawbacks. It has made us many easy solutions of finding what we want, but it has removed the smell of the books from our noses as well. It has made our path easier to follow and faster to reach, but it also has brought nervous because of the traffic jam and lack of the parking spot in our already busy lives. However, having not reached this level of development of any kind we would still has lived forgotten in the middle of old times, struggling for human rights and a bowl of rice. It cannot be said that in our world everything functions perfect and without any mistake, but it is the world with good basis of the next existence. Our new era started a big fight for making people unique and respected. It has raised the existence of women on a very new level. It returned to very past times and to our very infant stage of mind, trying to raise the common sense of respecting the planet and mutual relationship with her.

Considering above mentioned in multinational company we can see many movements of creating a less polluted area. In not so distant past, those movements were including women in the big machinery of ideas for prosperity. For multinational company it also refers to international human resources, where boundaries must been brought down.

Having fulfilled all of this tasks that have emerged into new society we came to a new resolution of will. We met face to face with maybe the, until these day, biggest task in humankind. Keep the one who is giving you, safe and give to the one who keeps you safe.

More or less, we all depend on electronics and machinery around us. Question that we see floating around our heads is how to maintain their presence and reduce the damage. Multinational company, one with full right to call itself a multinational again follows the employees and people. Company relies on human resources, one of the resources that if we learn how to keep it safe, will never stop to coexist with life and needs. Toyota Company is an excellent example of human relations company. It has started developing in one country, in time spread influence on world, and listened to people and together with them, today they are building new conception of great invention. A multinational company 
standing on human relations, which main products are cars, has to think of developing equally good quality, safe and trusted product.

In the very beginning of making cars for future use, they came up with an idea of making car that is going to be efficient in spending fuel and of very practical small size so it can fit anywhere. Since we entered in an era, where fuel is unstoppably disappearing, not only Toyota the carmaker has to find a new solution, but all of companies producing vehicles. Again, thanks to the good search in environment they found out that using less fuel, will not only save the nature, but will postpone the disappearance of the most valuable liquid in auto industry for now. This solution has shown up as a very good one. Next was to produce ecological vehicle. There it can be seen that sense of keeping the nature safe and refreshed has risen. They started thinking of making cars that can go on some ecological fuels, for what again people took the responsibility. Without people with connections with local people and employees of other companies, innovation has small chances to happen.

In order to survive in a place where free space for living and developing is becoming fortune, subsidiary items have to compact. So next to the saving fuel and developing substitute power, stands providing quality in small effective product. Effective, compact product means saving space and leaving it for developing other unnecessary facilities for making life easier to follow. Regarding Toyota Company it means a production of an, instead of enormous and awkwardly big gas consumption car, to small, ecological consumer of gas, efficient and reliable car. This product is known as Hybrid car. After long period of thinking what can be sustainable enough for entering the 21 century, they, thanks to company, already well functioned on the international human resources, developed a new product, fairly well for next few generations use.

After developing the car that will save fuel and space, new ways of saving planet has emerged. This new ways consider making future look cars, with use of some new, less harmful fuels. In a fight for surviving in an electronic era, successful companies, such as Toyota, have to think and to develop in flow of the needs of not only present generations, but new as well. This company has been developing many years, but always thanks to people, and always through looking in the future, never through looking in the past. Looking in the future helped with providing secure production and existence of constant relations between people and machines, never forgetting that we are much more capable to develop. Awareness of past and troubles they have met in reaching top quality products, helped in preserving same troubles again. Living in the present made Toyota company encourage the people to think and use knowledge achieved in past, for leisure life in future. Further future development will only show that this effort had its price and it will also show many unexpected ideas and brilliant productions, all thanks to multinational and international human cooperation. 


\section{CONCLUSION}

In the period of a big economical growth many companies with ideals for new tomorrow have developed. One among many others was Toyota Company. Members of Toyoda family saw the chance in realizing the ideas. Thanks to many programs proposed by government, people with great knowledge and skills have succeeded in rising from common and making the big chances. In period of establishing the company, government has offered chance to small business and local shops to spread thought Japan. This meant slow growth of economy, followed by developing skilled locals and employing ordinary, smart people. With an idea for opening a big successful company Toyoda, family started reaching the top of the rising companies.

Along with carefully paid attention with new emerged needs, small family business became a Toyota Company. In preserving and spreading ideas, they developed good quality products, which draw attention of buyers along the whole country. Keeping the old respected values in the working area, they maintained to bring more and more young people into the company. They knew that world would stand on the young people wanting and needs. Therefore, they constantly kept importing hard working, obedient and loyal people. In time, following good example this company had become nationally respected company.

With national recognition and with emerging of other competitive companies they needed new light on the way to success. This is the time when they started thinking of outside world and chances that are waiting to be realized. Slowly learning the meaning of other cultures and becoming used to existence of differences among people, they started sending young employees to the outside world in search for prosperity. Research has brought wonderful results. Gradually, young employees started bringing ideas of other countries needs, and employees in Japan started thinking of spreading the success worldwide. Slowly national company for good of one nation people became a multinational company for mutual good of all countries people they went to develop.

Multinational surrounding brought international success. Becoming internationally successful company was not easy. It included many troubles in facing with cultural differences and spanning the ways of one mind into another historically and culturally based thought. Nevertheless, they managed to develop many rules, which have been followed, all in order to keep good spirit and produce quality. Human being is one unpredictable creature. Working with many unpredicted creatures, erases the prejudices. It teaches us how to maintain together in all our differences and uniqueness. It teaches us how with combining those two things we can make an international, multinational wonder. Respecting human rights and developing new ideas along with them is a step made by Toyota Company, worth following. 
I plan to cut down on the slack time within work processes and in the shipping of parts and materials as much as possible. As the basic principle in realizing this plan, I will uphold the just in time approach. The guiding rule is not to have goods shipped too early or too late.

Kiichiro Toyoda, founder of Toyota Motor Company, $1938^{5}$

\section{LITERATURE}

Flath, 2005: David Flath. The Japanese Economy, second edition. Oxford University Press

Fujita, Kumagi, Nishikimi, 2008: Masahisa Fujita, Satoru Kumagi, Koji Nishikimi. Economic integration in East Asia, Perspectives from Spatial and Neoclassical Economics. Institute of Developing Economies (IDE), JETRO

Stratfor, 2009: THE GEOPOLITICS OF JAPAN: An Island Power Adrift. Stratfor Global intelligence

Harzing, Ruysseveldt, 2004: Anne-Will Harzing, Joris Van Ruysseveldt. International Human Resource Management, second edition. SAGE Publications London-Thousand OaksNew Delhi

Liker, 2004: Jeffrey K. Liker. The Toyota Way: 14 Management Principles from the World's Greatest Manufacturer. McGraw-Hill (C)

http://www.toyota-global.com/sustainability/corporate_citizenship/environment/toyota_environmental_activities_grant_program/

http://www.toyota.com.ph/about_tmp/index.asp

http://www.toyoland.com/toyota/production-system.html

5 Source: The Toyota way, Jeffery K. Liker 


\section{Микица А. ЈОТОВ}

\section{МУАТИНАЦИОНААНИ КОРПОРАТИВНИ ОАНОСИ У ЈАПАНСКОЈ КОМПАНИЈИ ТОЈОТА СА ОСВРТОМ НА САРААЬУ СА ФИАИПИНИМА}

\section{РеЗИме}

Овај рад има за циљ Аа размотри проблематику специјалног модела управљања и производње који је развијен у компанији Тоуота, и његов Аопринос развоју Аругих економија у свету, с посебним освртом на производњу на Филипинима.

Јапан је прва земьа у Азији која је кренула путем модернизације и као таква, постала модел земьама у окружењу. Филипини су једна од земаља Азијско-пацифичког региона која је следила пут промена и усвојила Каизен филозофију.

Јапан је утицао и шире, глобално, на све компаније у свету које тезе Аа у сопственом окружењу спроведу овакав начин пословања.

Пословна фимозофија компаније Тоуота и примена Каизена као новог модела руковођења корпорацијом, постала је синоним за квалитетно управљање компанија сиром света, те је утицала на успоставњање нових законитости у сфери економије, културе и Аруштва, у глобалном контексту.

Кьучне речи: Јапан, Филипини, Тојота, култура, економија

РаА је преАат 15. новембра 2020. године, а након мишьења рецензената, оАмуком одговорног уредника Башитине, одобрен за штампу. 